\title{
KEGIATAN LITERASI MELALUI MENDONGENG SEBAGAI UPAYA PENANAMAN MINAT BACA SISWA KELAS III SD NEGERI 4 KUTOSARI TAHUN AJARAN 2019/2020
}

\author{
Nurul Safitri ${ }^{1}$, Rokhmaniyah ${ }^{2}$, Moh. Salimi ${ }^{3}$ \\ Universitas Sebelas Maret, \\ nurulsafitri618@student.uns.ac.id
}

\section{Article History}

accepted 30/8/2021

\begin{abstract}
Indonesians have low reading interest.The study aimed to describe the implementation of literacy activity through storytelling and the impact on third grade students' reading interest of SD N 4 Kutosari. It was case study. The subjects were students and teacher of third grade of SD N 4 Kutosari. The data collection techniques were observation, interviews, questionnaire, and document study. The data collection techniques were source triangulation and technique triangulation. The result showed that were three stage of implementation of literacy activities through storytelling: (a) preparation, (b) storytelling activity, (c) evaluation. The implementation of literacy activities through storytelling have good impact on students' reading interest

Keywords: literacy, storytelling, reading Interest
\end{abstract}

Abstrak: Di Indonesia, minat membaca masyarakatnya masih berada pada taraf terendah. Penelitian ini bertujuan untuk mendeskripsikan pelaksanaan kegiatan literasi melalui mendongeng dan dampaknya terhadap minat baca siswa kelas III SDN 4 Kutosari. Penelitian ini adalah penelitian studi kasus. Subjek penelitian ini adalah siswa dan guru kelas III SDN 4 Kutosari. Teknik pengumpulan data penelitian ini menggunakan observasi, wawancara, angket dan studi dokumen. Teknik validitas data penelitian ini menggunakan triangulasi sumber dan triangulasi teknik. Hasil penelitian menunjukkan jika pelaksanaan kegiatan literasi melalui mendongeng dilaksanakan dengan 3 tahapan yaitu: (a) persiapan sebelum storytelling (tahap perencanaan), (b) tahap storytelling berlangsung dan, (c) setelah kegiatan storytelling (tahap evaluasi). Pelaksanaan kegiatan literasi melalui mendongeng memiliki dampak yang baik terhadap minat baca siswa.

Kata kunci: literasi, mendongeng, minat baca 


\section{PENDAHULUAN}

Membaca merupakan kegiatan yang sangat penting dalam kehidupan manusia. Setiap aspek kehidupan melibatkan kegiatan membaca. Pepatah lama mengatakan bahwa "membaca adalah jendela dunia" karena dengan membaca manusia dapat mengetahui banyak hal yang ingin diketahuinya. Menurut Tarigan (2015: 7) membaca adalah sebuah proses yang dilakukan oleh pembaca untuk mendapatkan pesan yang hendak disampaikan oleh penulis melalui media bahasa tulis. Menurut Ritchie, Bates, dan Plomin (2015), berbagai studi sudah menunjukkan bahwa kemampuan membaca berkaitan erat dengan tingkat kesehatan, pendidikan, dan ekonomi seseorang. Masyarakat yang gemar membaca akan memperoleh pengetahuan dan wawasan sehingga memungkinkan mereka dapat menjawab tantangan hidup di masa yang akan datang (Rahim, 2011: 1).

Walaupun membaca sangat bermanfaat, ternyata minat dan kemampuan membaca rakyat Indonesia masih rendah. Data Badan Pusat Statistik (BPS) pada tahun 2012 menyebutkan presentase hasil minat baca masyarakat yaitu menonton televisi $91,68 \%$, mendengarkan radio $18,57 \%$, dan membaca koran $17,66 \%$ (Munir,2016: 1). Temuan di atas, dikuatkan oleh survei UNESCO yang menyebutkan minat baca masyarakat Indonesia sangat memprihatinkan, hanya 0,001\% (Mardina, 2017). Artinya, dari seribu orang Indonesia, hanya satu orang yang rajin membaca. Riset berbeda bertajuk world's most literate nations ranked yang dilakukan oleh Central Connecticut State Univesity pada Maret 2016 lalu, Indonesia dinyatakan menduduki peringkat ke-60 dari 61 negara soal minat membaca, persis berada di bawah Thailand (59) dan di atas Bostwana (61). Padahal, dari segi infrastuktur yang mendukung kegiatan membaca, peringkat Indonesia berada di atas negara-negara Eropa. Dari seluruh hal yang telah disebutkan di atas, menjadi bukti yang kuat bahwasannya ternyata kegiatan membaca masih belum diminati oleh masyarakat.

Rendahnya minat baca dapat berdampak buruk bagi diri sendiri, masyarakat, dan negara. Witanto (2018: 9) menjelaskan kurangnya minat membaca dapat berdampak sangat merugikan, di antaranya akan terjadi masalah dalam memahami, menggunakan, menguasai, serta meneruskan IPTEK; (2) minimnya wawasan akan mempersempit pola pikir sehingga mudah terpengaruh oleh berbagai doktrin dan pemahaman negatif; (3) menyebabkan tidak berkembangnya kreatifitas seseorang; (4) menjadi tidak mengetahui informasi teraktual sehingga mengalami kesulitas untuk meningkatkan kualitas diri. Sangat memprihatinkan jika hal di atas terjadi pada generasi muda bangsa ini. Karena itu, sangat penting untuk meningkatkan kemampuan membaca pada rakyat Indonesia. Salah satu caranya adalah menumbuhkan minat baca pada anak sejak dini.

Sekolah merupakan salah satu tempat yang tepat untuk menumbuhkan minat baca. Cara yang dapat digunakan ialah dengan berliterasi. Hal tersebut sebagaimana dituangkan dalam buku panduan gerakan literasi sekolah (GLS) yang menyebutkan bahwa salah satu tujuan dilaksanakannya literasi ialah untuk menumbuhkan minat baca (Wiedarti, dkk., 2018: I). Mendongeng merupakan salah satu cara untuk mengenalkan literasi kepada siswa (Miller \& Pennycuff, 2008).

Mendongeng merupakan warisan budaya yang sangat menyenangkan namun dalamnya kaya akan manfaat dan pengetahuan. Siswa yang sudah terbiasa mendengarkan dongeng akan tumbuh keinginan untuk membaca buku (Kurniawan dalam Sumaryanti, 2018 : 119). Penelitian yang dilakukan oleh Mello menunjukkan bahwa bercerita membantu meningkatkan tingkat melek huruf para peserta dalam bidang-bidang akademis berupa kefasihan, penguasaan kosakata, penulisan, dan daya ingat (Miller dan Pennycuff, 2008). Lebih spesifik Poslaniec \& Houyel (Ekawati dkk,2017 : 572) berpendapat bahwa kesenangan yang dirasakan saat mendengarkan dongeng kemudian akan menumbuhkan perilaku membaca. Hal ini menunjukkan 
bahwa mendongeng dapat menjadi sarana yang efektif dalam menumbuhkan serta meningkatkan minat baca anak.

Sesuai dengan ulasan di atas, kegiatan mendongeng sejatinya penting sarana meningkatkan minat membaca. Namun, sangat disayangkan, tidak semua sekolah melaksanakan literasi dengan kegiatan mendongeng. Hal tersebut terbukti dari beberapa penelitian seperti yang dilakukan oleh Kurrotu'Aini, Azmi, dan Retno Nuzilatus. Penelitian ini tersebar di tiga daerah yakni daerah Jawa Tengah, Yogyakarta, dan Jawa Timur. Dari berbagai kegiatan literasi, sekolah pada umunya masih menggunakan metode yang konvensional yaitu diisi dengan kegiatan membaca 15 menit sebelum pembelajaran. Kegiatan ini dilakukan secara individu di kelas tanpa didampingi oleh guru.

Berbeda dengan kegiatan literasi di sekolah pada umumnya, SDN 4 Kutosari melaksanakan kegiatan literasi melalui mendongeng. Kegiatan mendongeng dilakukan dengan metode read aloud atau membaca nyaring. Kegiatan tersebut juga dilakukan secara bersama sama dan juga didampingi oleh guru. Kegiatan literasi tersebut juga diwujudkan dengan diadakannya pohon literasi. Kegiatan tersebut diadakan sebagai alternatif dari kegiatan membaca 15 menit sebelum pembelajaran yang dinilai kurang efektif. Oleh sebab itu, guru kelas III berinisiatif untuk melaksanakan literasi dengan mendongeng yang dirasa lebih menyenangkan sehingga siswa akan bersungguhsungguh dalam melaksanakan kegiatan literasi. Adanya kegiatan tersebut diharapkan menjadi penyampai pesan yang efektif kepada siswa bahwasannya membaca itu menyenangkan.

Didasari oleh latar belakang di atas, maka artikel ini dibuat untuk menjawab pertanyaan bagaimana pelaksanaan kegiatan literasi melalui mendongeng pada kelas III SD Negeri 4 Kutosari beserta dampaknya terhadap minat membaca siswa kelas III SDN 4 Kutosari? Dengan beberapa tujuan yakni untuk mendeskripsikan pelaksanaan kegiatan literasi melalui mendongeng pada kelas III SD Negeri 4 Kutosari beserta dampaknya terhadap minat membaca siswa kelas III SDN 4 Kutosari.

\section{METODE}

Penelitian ini merupakan penelitian kualitatif dengan menggunakan metode case study (studi kasus). Subjek penelitian ini adalah siswa dan guru kelas III SDN 4 Kutosari. Penelitian ini dilaksanakan di SDN 4 Kutosari yang berlangsung dari bulan maret 2020 sampai Juli 2020.

Penelitian ini mencari tahu mengenai pelaksanaan kegialatan literasi melalui mendongeng beserta dampaknya terhadap minat membaca siswa kelas III SDN 4 Kutosari. Melalui purposive sampling, sumber data dalam penelitian ini adalah, siswa, guru, dan orang tua dari siswa kelas IIII SDN 4 Kutosari.data dalam penelitian ini ada dua yaitu data mengenai pelaksanaan kegiatan literasi melalui mendongeng dan data minat membaca siswa.Teknik pengumpulan data menggunakan observasi, wawancara, dan studi dokumen. Validitas data dengan triangulasi sumber dan triangulasi teknik. Analisis data menggunakan teori Miles dan Huberman yaitu reduksi data, penyajian data, verifikasi.

\section{HASIL DAN PEMBAHASAN}

Pelaksanaaan kegiatan literasi melalui mendongeng di kelas III SDN 4 Kutosari dilaksanakan melaui tiga tahapan yakni sebelum mendongeng (tahap persiapan), tahap storytelling berlangsung, dan tahap setelah kegiatan storytelling.

Pada tahap persiapan, ditandai dengan adanya pemilihan judul buku atau judul dongeng dan pengkondisian siswa. Pemilihan judul dongeng dilakukan sendiri oleh 
guru dengan memperhatikan aspek aspek tertentu seperti isi dongeng yang disesuaikan dengan karakteristik siswa dan dikaitkan pula dengan pembelajaran yang akan dilakukan, serta kemenarikan dongeng. Dari kegiatan tersebut artinya guru telah melakukan pemilihan judul dongeng dengan menelaah dan mempelajari dan menganalisis tujuan yang akan dicapai dari isi dongeng serta mempersiapkan cara evaluasi yang akan dilakukan (Kusmiadi dkk, 2008 : 201). Selanjutnya pengkondisian siswa dilakukan dengan cara mengajak siswa berdoa, menfokuskan perhatian siswa, melakukan tepuk - tepuk, dan tidak lupa menyampaikan judul buku atau judul dongeng yang akan dibacakan. Hal tersebut sesuai dengan pendapat Kusmiadi dkk yang menyatakan bahwa sebelum mendongeng, guru sebaiknya melakukan Pijakan pengalaman yang dapat dilakukan dengan cara mengkondisikan anak, menyanyikan lagu anak-anak dan bermain tepuk bervariasi Kusmiadi dkk, 2008 : 201).

Pada saat tahap storytelling berlangsung, guru menyajikan beberapa hal di antaranya yaitu kontak mata, mimik wajah, gerak tubuh, suara, kecepatan, dan alat peraga. Kontak mata dilakukan menyebar pada seluruh siswa terutama mengarah pada siswa siswa yang dirasa kurang memperhatikan. Merespon hal tersebut, hampir setiap siswa yang dipandang menjadi lebih memperhatikan. Hal tersebut sejalan dengan pendapat Wardiah (2017: 48) yang menyatakan jika pendongeng melalukan kontak mata, maka audience akan merasa dirinya diperhatikan dan diajak untuk berinteraksi. Selain itu, dengan melakukan kontak mata kita dapat melihat apakah audience menyimak jalan cerita yang didongengkan. Guru sebagai pendongeng juga selalu mengekspresikan mimik wajah yang sesuai dengan keadaan ketika mendongeng. Peneliti mencatat bahwasannya dengan adanya penampilan mimik wajah, siswa menjadi turut merasakan situasi dalam cerita. Hal tersebut sejalan dengan pendapat Wardiah (2017: 48) yang menyatakan bahwa pada waktu storytelling, mimik wajah dapat menunjang hidup atau tidaknya sebuah cerita yang disampaikan. Pendongeng harus dapat mengekspresikan wajahnya yang sesuai dengan situasi yang didongengkan.

Selanjutnya guru sebagai pendongeng juga memperagakan gerakan dalam cerita. Gerakan dilakukan sesuai dengan isi cerita. Tak jarang guru juga mengajak siswa untuk menirukan gerakan yang ditampilkan. Merespon hal tersebut siswa terlihat sangat senang dan lebih ceria serta aktif. Hal tersebut sejalan dengan pendapat Wardiah (2017: 48) yang menyatakan bahwa gerak tubuh pendongeng saat proses storytelling dapat menggambarkan jalan cerita yang lebih menarik. Cerita yang didongengkan akan terasa berbeda jika pendongeng melakukan gerakan yang merefleksikan apa yang dilakukan tokoh cerita. Dalam menyajikan storytelling, guru sebagai juga memperhatikan intonasi suara. Intonasi suara yang dipergunakan dinamis menyesuaikan dengan kondisi yang diceritakan. Ketika menggambarkan suasana hati yang sedih intonasi suara yang dikeluarkan cenderung lirih dan rendah. Ketika menggambarkan suasana hati yang marah, nada suara yang dipergunakan cenderung keras dan tinggi. Dan ketika menggambarkan suasana hati yang bahagia, nada suara yang dipergunakan cenderung keras dan ceria. Selain itu guru juga menggunakan suara yang berbeda - beda pada setiap tokohnya. Suara yang dipergunakan menyesuaikan dengan karakter tokoh dalam cerita. Hal tersebut sejalan dengan pendapat Wardiah (2017: 48) yang menyatakan bahwa rendah tidaknya suara yang diperdengarkan dapat digunakan oleh pendongeng untuk membawa audience merasakan situasi di dalam cerita

Aspek lain yang juga diperhatikan oleh guru pada saat storytelling berlangsung sialah kecepatan. Kecepatan yang dimaksud di sini ialah kecepatan nada atau suara. Durasi cerita yang dibawakan tidak pernah lebih dari 15 menit. Selain itu tempo suara yang digunakan juga sedang - sedang saja. Kecepatan yang dilakukan tidak boleh terlalu cepat ataupun terlalu lambat (Wardiah, 2017: 48) Pada penggunaan alat peraga ditemukan bahwa penggunaanya dapat dikatakan belum maksimal. Alat peraga hanya 
mewakili moderator dan tidak seluruh adegan dalam cerita diperagakan oleh alat peraga. Peneliti juga menemukan bahwa siswa lebih tertarik dan antusias terhadap cerita yang dibawakan dengan adanya alat peraga. Untuk menarik minat anak-anak dalam storytelling, perlu adanya alat peraga untuk mewakili tokoh cerita. misalnya boneka kecil yang dipakai di tangan, wayang, dan lainnya (Wardiah, 2017: 48).

Tahap yang terakhir ialah tahap setelah kegiatan mendongeng atau disebut juga sebagai tahap evaluasi. evaluasi dilakukan dengan menggunakan metode tanya jawab mengenai unsur cerita berupa tokoh, amanat, watak dan sebagainya. Bagi siswa yang mampu menjawab pertanyaan dapat menuliskannya dan menempelkan jawaban pada pohon literasi yang tersedia di depan kelas. Selain itu untuk mengurangi ketegangan, seusai kegiatan tanya jawab selesai tak lupa pula guru mengajak siswa untuk bernyanyi maupun melakukan tepuk tepuk. Di akhir kegiatan, siswa diminta untuk mencatat dongeng yang telah dibacakan. Seusai kegiatan mendongeng dilakukan, guru dan siswa bersama- sama membuat kesimpulan mengenai pesan moral yang terdapat dalam cerita atau disebut sebagai Experience Sharing Proces. Maksud dari Experience Sharing Proces pembagian pengalaman tentang hal-hal yang terkait dengan topik penceritaan (Wardiah, 2017: 53).

Secara keseluruhan pengukuran dampak kegiatan literasi melalui mendongeng terhadap minat membaca siswa mendapat hasil bahwa 9 siswa mendapatkan predikat minat membaca cukup, 8 siswa menyandang predikat minat membaca tinggi, dan 7 siswa menyandang predikat minat membaca sangat tingg. Dengan demikian dapat dikatakan minat membaca semua anak baik. Masing - masing aspek akan dijelaskan di bawah ini.

Aspek pertama pada minat baca ialah pemusatan perhatian. Terdapat dua indikator dari aspek ini yaitu mampu melaksanakan kegiatan membaca secara fokus. Pada indikator mampu melaksanakan kegiatan membaca secara fokus, hampir semua siswa menjawab Ya pada kedua pernyataan yang diberikan yaitu "saya fokus ketika membaca" dan "saya tidak ingin diganggu ketika membaca". Selanjutnya pada indikator mampu melaksanakan kegiatan membaca secara aktif, lebih dari setengah jumlah siswa menjawab Ya pada tiga poin pernyataan "setiap ada kegiatan kelompok, saya maju untuk membaca hasil diskusi", "saya senang membacakan buku untuk teman teman/ adik di rumah", dan "saya terbiasa membaca di depan teman - teman". Beberapa alasan menjawab tidak dikarenakan malu maju ke depan dan tidak memiliki adik dan jarang bergaul di rumah.Sedangkan untuk pernyataan "saya senang membacakan buku untuk teman teman/ adik di rumah" hanya 1 siswa yang menjawab Tidak.

Dari pemaparan di atas, dapat dikatakan bahwa sebagian besar siswa telah memiliki pemusatan perhatian yang baik. Hal tersebut sesuai dengan pendapat Sudarsana dan Bastiano (2013: 1.7) suatu minat dapat diekspresikan melalui partisipasi dalam bentuk aktivitas. Seseorang yang memiliki minat terhadap objek tertentu cenderung memberikan perhatian yang lebih terhadap objek tersebut, karena pemusatan perhatian yang intensif terhadap sesuatu dapat memungkinkan kita untuk lebih giat dan akhirnya mencapai target yang diinginkan.

Untuk aspek yang kedua yakni penggunaan waktu yang memiliki idikator mampu menggunakan waktu secara efektif, sebanyak 16 siswa menjawab Ya pada pernyataan "Jika jam istirahat saya pergi membaca buku" sedangkan sisanya menjawab tidak dengan alasan dengan alasan jam istirahat dipergunakan untuk istirahat. Dan pada pernyataan "Jika guru tidak masuk kelas, saya membaca buku" dijawab Ya oleh 15 siswa sisanya menjawab Tidak biasanya diberi tugas.

Dari pemaparan di atas, dapat dikatakan bahwa sebagian besar siswa memiliki penggunaan waktu yang efektif untuk membaca. Seseorang yang mempunyai minat baca adalah orang yang di dalam hidupnya selalu berusaha menggunakan sebagian waktunya untuk membaca (Sutarno, 2003: 19) 
Pada aspek yang ketiga yakni menunjukkan motivasi terhadap kegiatan membaca. Indikator dari aspek tersebut ialah mampu mengatasi hambatan membaca, mampu mengutamakan membaca dari pada pekerjaan yang lain, dan mampu menunjukkan prestasi belajar. Pada indikator mampu mengatasi hambatan membaca, hampir semua anak menjawab Ya pada dua pernyataan "Ketika saya belum memahami bacaan saya, membaca buku berulang-ulang sampai paham" dan pernyataan "Jika saya merasa bosan dengan buku yang saya baca, mencoba mencari buku lain yang lebih menarik" sisanya menjawab tidak dengan alasan pasrah. Lalu pada indikator mampu mengutamakan membaca dari pada pekerjaan yang lain, Sebanyak 23 menjawab Ya pada pernyataan "Saya lebih suka membaca buku dari pada berolah raga". Selanjutnya untuk pernyataan "saya lebih suka membaca buku dari pada bergurau" dan pernyataan "Saya lebih suka membaca buku dari pada menonton TV" kedua pernyataan tersebut mendapatkan Ya dari 20 anak. Sisanya menjawab tidak dengan alasan bergurau dan menonton tv merupakan kebiasaan. Dan yang terkahir yaitu "saya lebih suka membaca buku dari bermain game" 19 anak menjawab Ya. Pada indikator mampu menunjukkan prestasi belajar, sebagian besar siswa menyatakan Ya. Sisanya menjawab tidak dengan alasan game merupakan permainan yang disukai. Dan pada pernyataan "Saya merasa mudah memahami materi pembelajaran". Dan 20 siswa juga menyatakan Ya pada pernyataan "Saya merasa mudah mengerjakan soal yang diberikan oleh guru" sedangkan sisanya memilih Tidak dengan alasan tidak semua pelajaran dapat dipahami.

Dari seluruh pemaparan di atas, dapat dikatakan bahwa siswa telah memiliki motivasi untuk membaca. Seorang anak yang menyukai suatu aktivitas, biasanya akan termotivasi dan mau melakukan aktivitas tersebut. Dalam hal ini minat membaca berarti mengandung motivasi untuk melakukan aktivitas membaca (Sudarsana dan Bastiano, 2013: 14)

Untuk aspek yang keempat yakni emosi dalam membaca. Pada aspek ini, terdapat beberapa indikator untuk mengukurnya yakni mampu menyimpulkan hasil dari membaca, mampu memberikan tanggapan terhadap buku yang dibaca, dan mampu melaksanakan kegiatan dengan rasa senang tanpa keterpaksaan. Pada indikator mampu menyimpulkan hasil dari membaca, sebagian besar siswa menjawab Ya pada dua pernyataan yakni "Saya dapat menyimpulkan isi bacaan yang saya baca" dan "Saya dapat menceritakan isi bacaan yang saya baca". Beberapa siswa menjawab tidak dengan alasan menyimpulkan adalah hal yang sulit. Selanjutnya pada indikator mampu memberikan tanggapan terhadap buku yang dibaca, lebih dari setengah jumlah siswa yakni 17 siswa menjawab Ya pada pernyataan "saya dapat melihat kelebihan dan kekurangan bacaan yang saya baca". Lalu hampir seluruh siswa menjawab Ya pada pernyataan "saya dapat menilai bagus tidaknya buku yang saya baca" hanya 4 siswa yang memilih Tidak dengan alasan semua buku sama saja. Dan Indikator terakhir dari komponen ini ialah mampu melaksanakan kegiatan dengan rasa senang tanpa keterpaksaan. Pada indikator ini, hampir seluruh siswa menjawab Ya pada tiga pernyataan yang diberikan yakni "saya membaca buku karena keinginan saya sendiri", "membaca adalah hiburan saya", dan "membaca membuat saya senang" hanya 2 siswa saja yang menjawab Tidak. Selanjutnya pada pernyataan "Membaca adalah hoby saya" dijawab Ya sebanyak 18 siswa sedangkan 8 siswa memilih Tidak dengan alasan memiliki hobby lain seperti berolahraga, berenang, dan bersepeda.

Dari penjelasan di atas, menunjukkan bahwa siswa kelas III telah memiliki emosi dalam membaca. Membaca memerlukan Dorongan dari dalam individu diwujudkan dengan rasa ingin tahu siswa yang membangkitkan kegiatan membaca. Dalam hal ini yang dimaksud ialah emosi. Emosi diwujudkan dengan perasaan siswa ketika membaca, apakah itu senang atau sebaliknya (Crow dan Crow dalam Shaleh dan Wahab, 2004: $264-265)$. 
Aspek yang terakhir dari minat baca yakni usaha untuk membaca. Pada aspek ini terdapat dua indikator yakni mampu memiliki buku bacaan dan mampu meminjam buku bacaan. Pada indikator mampu memiliki buku bacaan, seluruh siswa menjawab Ya pada pernyataan "saya memiliki buku di rumah". selaras dengan hal itu ketika diberikan pernyataan yang bersifat kebalikan, seluruh siswa menjawab Tidak pada pernyataan "saya tidak memiliki buku satupun". Dan hampir seluruh siswa juga menjawab Ya pada pernyataan "saya memiliki koleksi buku favorit di rumah" hanya 2 siswa saja yang Tidak. Namun sangat disayangkan lebih dari setengah jumlah siwa tidak terbiasa membeli buku. Hanya 12 siswa yang menjawab $\mathrm{Ya}$ pada pernyataan "saya terbiasa membeli buku" sedangkan 14 siswa memilih Tidak dengan alasan tidak diajak untuk membeli buku. Indikator selanjutnya ialah mampu meminjam buku bacaan. Pada indikator ini lebih separuh dari jumlah siswa menjawab Ya pada pernyataan "saya biasa meminjam buku di perpustakaan" dan hampir seluruhnya menjawab Ya pada pernyataan "jika tidak memiliki buku, saya berusaha meminjam buku" hanya 2 siswa saja yang menjawab Tidak.

Dari penjabaran di atas, dapat dikatakan bahwa siswa kelas III telah memiliki usaha untuk membaca. Di mana, usaha dalam membaca merupakan salah satu indikator dari minat baca. Minat sangat menentukan sukses tidaknya seseorang dalam melaksanakan kegiatannya. Minat yang besar akan mendorong seseorang untuk melakukan hal-hal yang lebih baik, sebab dengan adanya minat dan perhatian maka usahanya akan timbul untuk melakukan kegiatan tersebut (Hamalik dalam Hardi, 2014: 2).

Seluruh hasil mengenai keadaan minat membaca yang telah dijabarkan di atas, senada dengan pendapat Crow and Crow (Hardi, 2014: 4) menyebutkan Indikator minat membaca meliputi: pemusatan perhatian, penggunaan waktu, motivasi untuk membaca, emosi dalam membaca, dan usaha untuk membaca.

\section{SIMPULAN}

Berdasarkan hasil penelitian dan pembahasan dapat disimpulkan jika pelaksanaan kegiatan literasi melalui mendongeng pada kelas III SD Negeri 4 Kutosari sudah melalui 3 tahapan yaitu persiapan sebelum storytelling (tahap perencanaan), tahap storytelling berlangsung, dan setelah kegiatan storytelling atau disebut sebagai tahap evaluasi. Persiapan sebelum storytelling (tahap perencanaan), ditandai dengan adanya pemilihan judul buku atau judul dongeng dan pengkondisian siswa. Selanjutnya pada tahap storytelling berlangsung, guru memperhatikan beberapa hal yakni kontak mata, mimik wajah, gerak tubuh, suara, kecepatan, dan juga menggunakan alat peraga. Tahap terakhir ialah setelah kegiatan Storytelling atau disebut sebagai tahap evaluasi yang dilakukan dengan menggunakan metode tanya jawab kepada siswa mengenai unsur cerita selain itu juga melakukan kegiatan lain seperti bernyanyi dan melakukan tepuk tepuk. Dan tak lupa siswa diminta untuk mencatat. Penerapan kegiatan literasi melalui mendongeng di SDN 4 Kutosari juga mampu menumbuhkan minat membaca siswa. Dimana, pelaksanaan kegiatan literasi melalui mendongeng pada kelas III SDN 4 Kutosari berdampak terhadap tingginya minat baca siswa kelas III yang mendapatkan hasil bahwa presentase minat membaca yang diperoleh semua siswa berada pada kategori cukup, tinggi, dan sangat tinggi atau dengan kata lain minat membaca semua anak baik.

Berdasarkan uraian hasil penelitian, implikasi dari penelitian ini yaitu: (1) Bagi guru, penelitian ini dapat memberikan pengetahuan tentang pelaksanaan kegiatan literasi melalui yang mampu memberikan dampak positif terhadap minat membaca siswa; (2) Bagi siswa, penelitian ini dapat menumbuhkan minat membaca sehingga siswa memiliki minat membaca yang tinggi; (3) Bagi sekolah, penelitian ini memberikan wacana yang produktif bagi kepala sekolah untuk menumbuhkan minat membaca 
siswa melalui penerapan kegiatan literasi melalui mendongeng; (4) Bagi peneliti selanjutnya, penelitian ini dapat menjadi acuan pada saat melaksanakan penelitian.

\section{DAFTAR PUSTAKA}

Ekawati, D., Rachmat, A., Handayani, VT., Witakania. (2017). Metode Mendongeng dan Pengembangan Budaya Literasi Pada Anak Usia Dini. Jurnal The 1st International Conference on Language, Literature and Teaching, 2549-5607 diperoleh tanggal 18 Desember 2019 dari https://publikasiilmiah.ums.ac.id

Hardi. (2014). Pengaruh Minat Membaca Buku Terhadap Hasil Belajar Mahasiswa BKKN Akuntansi. (Artikel Penelitian)

Kusmiadi, dkk (2008). Strategi Pembelajaran Paud Melalui Metode Dongeng Bagi Pendidik Paud. Jurnal IImiah Visi, Vol 3 No 2 diperoleh tanggal 30 September 2020 dari media.meneliti.com

Mardina, R. (2017). Literasi Digital Bagi Generasi Digital Natives, Prosiding Conference Paper diperoleh pada tanggal 30 Januari 2021 dari https://www.researchgate.net

Miller, S., \& Pennycuff, L (2008). The Power of Story: Using Storytelling to Improve Literacy Learning. Journal of Cross-Disciplinary Perspectives in Education, Vol. 1 , No. 1 diperoleh pada tanggal 30 Januari 2021 dari https://www.researchgate.net

Munir, S. (2016, 28 April). Minat Baca Rendah, Mayoritas Warga Indonesia Hobi Nonton Televisi, KOMPAS, diperoleh tanggal 18 Desember 2019

Rahim, F. (2011). Pengajaran Membaca di Sekolah Dasar. Jakarta: Bumi Aksara

Ritchie,S.J., Bates, T.C., \& Plomin, R. (2015). Does learning to read improve intelligence? A longitudinal multivariate analysis in identical twins from age 7 to 16. Child Development, Vol.86, No 1, diperoleh pada tanggal 30 Januari 2021 dari https://www.ncbi.nlm.nih.gov

Shaleh, Wahab A. R. (2004). Psikologi Suatu Pengantar dalam Perspektif Islam. Jakarta: Kencana.

Sudarsana, U \& Bastiano. (2013). Pembinaan Minat Baca. Jakarta: Universitas Terbuka

Sumaryanti, L. (2018). Membudayakan Literasi Pada Anak Usia Dini Dengan Metode Mendongeng. Journal Basic Of Education, 2548-9992 diperoleh tanggal 18 Desember 2019 dari https://www.researchgate.net

Sutarno. (2003). Perpustakaan dan Masyarakat. Jakarta: Yayasan Obor Indonesia

Tarigan, H.G. (2015). Membaca Sebagai Suatu Keterampilann Berbahasa. Bandung: Angkasa

Wardiah, B. (2017). Peran Sorytelling Dalam Meningkatkan Kemampuan Menulis, Minat Membaca dan Kecerdasan Emosional Siswa. Jurnal Wahana Didaktika, Vol. 15 No. diperoleh tanggal 15 Januari 2020 dari jurnal.univpgripalembang.ac.id

Wiedarti, P., Laksono, K., Retnaningdyah, P., Dewayani, S., Muldian, W., Sufayadi, S., et all. (2018). Desain Induk Gerakan Literasi Sekolah. Jakarta: Kemendikbud

Witanto, J. (2018). Minat Baca Yang Sangat Rendah, Artikel 324182095. diperoleh tanggal 18 Desember 2019 dari https://www.researchgate.net 